\begin{tabular}{|l|c|c|} 
Submission: & $\begin{array}{c}\text { Article History } \\
\text { Review: } \\
2020-06-06\end{array}$ & $\begin{array}{c}\text { Accepted: } \\
2020-06-08\end{array}$ \\
2020-05-05 & Doi: https://doi.org/10.33367/ijies.v3i1.1138
\end{tabular}

\title{
Strategi Kepala Sekolah dalam Meningkatkan Literasi Membaca Siswa di SMA Negeri 1 Kota Kediri
}

\author{
Muhammad Rijal Mahfudh, ${ }^{1}$ Ali Imron ${ }^{2}$ \\ ${ }^{1}$ Institut Agama Islam Tribakti (IAIT) Kediri, ${ }^{2}$ Institut Agama Islam Tribakti (IAIT) Kediri \\ 1'm.rmahfudh07@ gmail.com, ${ }^{2}$ aliimron2009@gmail.com
}

\begin{abstract}
This study discusses how in potential for literacy needed by education. Student literacy ability is closely related to the guidance of reading skills analytically, critically, and reflectively. However, the fact of learning at school this time has not been able to realize it well. Principals as leaders and at the same time policy holders must have the right strategy. This is a great homework for all educational institutions in Indonesia, including in the city of kediri. This research uses qualitative methods with descriptive approaches, data collection methods in the form of observation, interviews, and documentation. Checking the validity of the data using triangulation. Data analysis through steps, compile, manage, and combine all data obtained from the field so that it becomes a conclusion. The results of the study show that the principal's strategy in improving reading literacy is for students, first, the level of habituation. Second, student literacy is directed at religious reading literacy. Third, forming a literacy team. This has not been said to be maximum because the school has obstacles. First, student reading facilities are only libraries. Second, the delay in students can make students abilities, skills and insights different from student who are disciplined.
\end{abstract}

Keywords: Headmaster, Reading Literacy, Strategy.

Abstrak
Studi ini membahas bagaimana potensi literasi yang dibutuhkan oleh
pendidikan. Kemampuan membaca siswa berkaitan erat dengan bimbingan
keterampilan membaca secara analitis, kritis, dan reflektif. Namun, fakta
belajar di sekolah saat ini belum mampu mewujudkannya. Kepala sekolah
sebagai pemimpin dan pada saat yang sama pemegang kebijakan harus
memiliki strategi yang tepat. Ini adalah pekerjaan rumah yang bagus untuk
semua lembaga pendidikan di Indonesia, termasuk di Kota Kediri. Penelitian
ini menggunakan metode kualitatif dengan pendekatan deskriptif, metode
pengumpulan data dalam bentuk, observasi, wawancara, dan dokumentasi.
Memeriksa validitas data menggunakan triangulasi. Analisis data melalui
langkah-langkah, mengompilasi, mengelola, dan menggabungkan semua data
yang diperoleh dari lapangan sehingga menjadi kesimpulan. Hasil penelitian
menunjukkan bahwa strategi kepala sekolah dalam meningkatkan literasi
membaca adalah untuk siswa, pertama, tingkat habituasi. Kedua, literasi
siswa diarahkan pada literasi membaca agama. Ketiga, membentuk tim
literasi. Ini belum dikatakan maksimal karena sekolah memiliki kendala.


Pertama, fasilitas membaca siswa hanya perpustakaan. Kedua, keterlambatan siswa dapat membuat kemampuan, keterampilan, dan wawasan siswa berbeda dari siswa yang disiplin.

Kata Kunci: Kepala Sekolah, Literasi Membaca, Strategi.

\section{Pendahuluan}

Pada abad ke-21 ini, dorongan untuk meningkatkan kemampuan literasi dasar semakin menguat. Karena peserta didik memerlukan 16 keterampilan agar mampu bertahan dan mampu berkompetisi hingga tingkat global. Keenam belas keterampilan itu terangkum menjadi 3 aspek yaitu literasi, kompetensi, dan karakter. Di mana aspek literasi mencakup enam keterampilan, antara lain literasi baca-tulis, numerasi, sains, digital, finansial, budaya dan kewargaan. ${ }^{1}$ Alasan lain yang mendorong peningkatan aspek literasi juga tampak dari hasil penilaian Programme for International Student Assessment (PISA) 2015 yang menunjukkan bahwa rata-rata peserta didik Indonesia berada pada peringkat ke-64 dari 72 negara. Hasil penilaian ini merupakan salah satu fakta pembelajaran di sekolah belum mampu mewujudkannya secara baik. ${ }^{2}$ Penilaian ini juga merupakan alarm bagi semua praktisi pendidikan untuk membenahi program pembelajaran agar kualitas pendidikan mengalami kemajuan. Hal ini dapat dilihat dari penilaian PISA 2018 (skor 371 poin dari skor rata-rata sebesar 487 poin) yang secara jelas menunjukkan siswa Indonesia mengalami penurunan kemampuan membaca dibandingkan dengan PISA 2015 (skor 397 dari skor rata-rata 493 poin). ${ }^{3}$

Di sisi lain, perpustakaan nasional juga mencatat bahwa rata-rata orang Indonesia hanya membaca buku 3-4 kali perminggu, dengan durasi waktu membaca per hari rata-rata 30-59 menit. Sedangkan jumlah buku yang selesai dibaca setiap tahun rata-rata antara 5 sampai 9 buku. Hal itu di ungkapkan, Menteri Kordinator Bidang Pembangunan Manusia dan Kebudayaan (PMK) Puan Maharani di gedung Perpustakaan Nasional. ${ }^{4}$ Kajian ini juga menunjukkan rendahnya minat baca siswa

\footnotetext{
1 Satgas Gerakan Literasi Sekolah Kemendikbud, Desain Induk Gerakan Literasi Sekolah (Jakarta: Direktorat Jenderal Pendidikan Dasar dan Menengah Kementerian Pendidikan dan Kebudayaan, 2016), 7-8.

2 Agus Widayoko, Supriyono Koes H, dan Muhardjito Muhardjito, "Analis is Program Implementasi Gerakan Literasi Sekolah (GLS) Dengan Pendekatan Goal-Based Evaluation,” Jurnal Tatsqif 16, no. 1 (9 Juli 2018): 78-92, https://doi.org/10.20414/jtq.v16i1.134.

3 Maimunatun Habibah, "Pengembangan Budaya Literasi Agama Di SMA Negeri 2 Kediri," Indonesian Journal of Islamic Education Studies (IJIES) $2, \quad$ no. 2 (2019): 203-15, https://doi.org/10.33367/ijies.v2i2.1110.

4 Kompas Cyber Media, "Per Hari, Rata-rata Orang Indonesia Hanya Baca Buku Kurang dari Sejam," KOMPAS.com, diakses 30 Januari 2019, https://nasional.kompas.com/read/2018/03/26/14432641/perhari-rata-rata-orang-indonesia-hanya-baca-buku-kurang-dari-sejam.
} 
Indonesia dibandingkan dengan negara lain. Hal itu terjadi hampir di seluruh wilayah, tidak terkecuali di Kota Kediri. Berkaitan dengan itu, Ilman Lathif menginformasikan jumlah pengunjung perpustakaan di Kota Kediri dalam satu bulan kurang dari 50 siswa dan mayoritas pengunjung yang hadir dikarenakan mereka membutuhkan referensi untuk mengerjakan tugas. ${ }^{5}$

Keadaan ini menunjukkan masih lemahnya kesadaran siswa dalam berliterasi. Meskipun sebenarnya, pemerintah sudah meluncurkan program literasi sejak akhir tahun 2015 yang dikenal sebagai Gerakan Literasi Bangsa (GLB), ${ }^{6}$ atau sekarang disebut dengan Gerakan Literasi Nasional (GLN). Program ini dimaksudkan untuk menumbuhkembangkan budaya literasi pada ekosistem pendidikan mulai dari keluarga, sekolah, dan masyarakat dalam rangka pembelajaran sepanjang hayat sebagai upaya untuk meningkatkan kualitas hidup. ${ }^{7}$ Upaya ini merupakan niat baik dan wujud perhatian pemerintah atas kondisi lemahnya literasi nasional yang sangat disayangkan jika hanya menjadi sebuah formalitas dan sekedar program kerja yang tidak berdampak apapun pada diri siswa, guru, dan masyarakat.

Optimalisasi program ini juga membutuhkan partisipasi aktif para pemangku kepentingan pada semua tingkat dan jenis pendidikan yang mencakup keseluruhan ekosistem sekolah. Selain itu, pendekatan pembelajaran yang berpihak pada seluruh komponen literasi juga perlu digunakan untuk memfasilitasi program tersebut. ${ }^{8}$ Karena optimalisasi suatu program tidak akan berjalan baik apabila tidak melibatkan seluruh komponen sekolah. Untuk itu, peran kepala sekolah menjadi semakin penting karena posisinya sebagai pemangku kebijakan sekaligus ujung tombak kemajuan sebuah lembaga pendidikan.

Berkenaan dengan itu, Yulmawati menemukan enam strategi peningkatan kualitas sekolah antara lain penyusunan perencanaan dan pengembangan sekolah, pelaksanaan strategi, meningkatkan hasil ujian nasional setiap tahun, mengadakan ekstrakurikuler, menjalin kerjasama dengan semua pihak, evaluasi pelaksanaan

\footnotetext{
5 Ilman Lathif, "Rendahnya Minat Baca Pelajar Kota Kediri - Kompasiana.com," diakses 30 Januari 2019, https://www.kompasiana.com/muhammadilmanlathif/552b7d8c6ea834c06a8b4586/rendahnyaminat-baca-pelajar-kota-kediri.

6 I. Made Ngurah Suragangga, "Mendidik Lewat Literasi untuk Pendidikan Berkualitas," Jurnal Penjaminan Mutu 3, no. 2 (31 Agustus 2017): 154-63, https://doi.org/10.25078/jpm.v3i2.195.

${ }^{7}$ Satgas Gerakan Literasi Sekolah Kemendikbud, Desain Induk Gerakan Literasi Sekolah.

8 Yulisa Wandasari, "Implementasi Gerakan Literasi Sekolah (GLS) Sebagai Pembentuk Pendidikan Berkarakter,” JMKSP (Jurnal Manajemen, Kepemimpinan, Dan Supervisi Pendidikan) 2, no. 2 (28 Desember 2017), https://doi.org/10.33369/jmksp.v2i2.1480.
} 
program. $^{9}$ Fatikah dan Fildayanti juga menginformasikan pentingnya peran dan fungsi kepala sekolah sebagai motivator karena motivasi yang diberikan kepala sekolah pada guru akan memberikan dampak positif pada kinerja guru sebagaimana tampak pada motivasi guru pada kebutuhan prestasi dan status yang dapat dilihat dari semangat guru untuk melanjutkan kuliah pada jenjang magister, sikap disipilin, dan tanggung jawab di SMAN Bareng. ${ }^{10}$ Selain itu, Makhromi dan Budiono menemukan bahwa peran guru sebagai manajer berkontribusi positif pada peningkatan mutu pendidikan. ${ }^{11}$ Dengan demikian, seorang kepala sekolah harus memiliki kreatifitas, inovasi, dan strategi yang mendukung program pengembangan sekolah, khususnya mengenai literasi dasar sebagai fondasinya. Usaha ini berangkat dari fakta lemahnya tingkat literasi siswa sehingga optimalisasi program literasi menjadi penting untuk meningkatkan kesadaran dan kompetensi literasi siswa yang pada waktu tertentu juga menjadi sebuah budaya baru di sekolah.

Beberapa kajian di atas menunjukkan betapa kompleksnya ruang yang dapat dimainkan kepala sekolah untuk meningkatkan kualitas lembaganya. Kompleksitas ini bukan tanpa alasan, tapi memang sesuai dengan tugas dan fungsi kepala sekolah. Oleh karena itu, kajian ini akan berupaya untuk mengungkap peran kepala sekolah dalam merumuskan hingga menerapkan strategi implementasi program literasi membaca di SMA Negeri 1 Kota Kediri, kemudian mengidentifikasi faktor-faktor pendukung dan penghambatnya dalam kerangka konsep evaluasi implementasi strategi.

\section{Metode Penelitian}

Pendekatan penelitian yang digunakan dalam penelitian ini adalah penelitian kualitatif, dengan metode pengumpulan data berupa observasi, interview, dan dokumentasi. $^{12}$ Proses interview dilakukan dengan menggali informasi dari informan kunci yakni kepala sekolah SMA Negeri 1 Kota Kediri. Sedangkan dokumentasi yang digunakan berupa data-data arsip dan galeri foto sekolah SMAN 1 Kota Kediri. Data

\footnotetext{
9 Yulmawati Yulmawati, "Strategi Kepemimpinan Kepala Sekolah Dalam Meningkatkan Mutu Pendidikan SD Negeri 03 Sungayang," JMKSP (Jurnal Manajemen, Kepemimpinan, Dan Supervisi Pendidikan) 1, no. 2 (1 April 2017), https://doi.org/10.33369/jmksp.v1i2.1012.

10 Noor Fatikah dan Fildayanti, "Strategi Kepala Sekolah Dalam Peningkatan Motivasi Dan Etos Kerja Guru Di Sekolah Menengah Atas Negeri Bareng Jombang," Indonesian Journal of Islamic Education Studies (IJIES) 2, no. 2 (30 Desember 2019): 167-82, https://doi.org/10.33367/ijies.v2i2.989.

11 Makhromi Makhromi dan Mahbub Budiono, "Kontribusi Kepala Sekolah Sebagai Manajer Untuk Meningkatkan Mutu Pendidikan Di MTs Negeri Kanigoro Kras Kediri," Indonesian Journal of Islamic Education Studies (IJIES) 2, no. 1 (31 Juli 2019): 78-93, https://doi.org/10.33367/ijies.v2i1.833.

${ }^{12}$ S Margono, Metodologi Penelitian Pendidikan (Jakarta: Rineka Cipta, 2003), 165.
} 
yang diperoleh dianalisis secara deskriptif kualitatif. ${ }^{13}$ Analisis data ini dipakai atau digunakan untuk menyusun, mengelola dan menghubungkan semua data yang didapatkan dari lapangan sehingga menjadi sebuah kesimpulan. Pada proses ini penulis juga melakukan pengecekan data dari hasil wawancara yang berhubungan dengan strategi kepala sekolah dalam meningkatkan literasi membaca siswa SMAN 1 Kota Kediri.

\section{Pembahasan}

\section{Tinjauan tentang Kepala Sekolah dan Literasi Membaca}

Kepala sekolah adalah guru yang bertugas untuk memimpin dan mengelola satuan pendidikan dari jenjang dasar hingga menengah. ${ }^{14}$ Sebagai pemimpin, kepala sekolah mempunyai beberapa dimensi kompetensi, yaitu kompetensi kepribadian, manajerial, kewirausahaan, supervisi, dan sosial. ${ }^{15}$ Kompetensi di sini mencakup pengetahuan, sikap, dan keterampilan yang melekat pada kelima dimensi kompetensi tersebut. Beban kerja kepala sekolah sepenuhnya untuk melaksanakan tugas pokok manajerial, pengembangan kewirausahaan, dan supervisi kepada guru dan tenaga kependidikan yang bertujuan untuk mengembangkan sekolah dan meningkatkan mutu sekolah berdasarkan delapan standar nasional pendidikan. ${ }^{16}$

Strategi kepala sekolah dalam mengembangkan lembaga dan mutunya adalah bagian dari dimensi kompetensi manajerial yang terdiri dari tujuh kompetensi. Dalam melaksanakan tugas sebagai manager, kepala sekolah harus mempunyai strategi untuk memberdayakan seluruh unsur sekolah secara kooperatif dan memberikan kesempatan pada mereka untuk meningkatkan profesinya dan mendorong mereka untuk meningkatkan program sekolah. ${ }^{17}$ Penjelasan ini berkaitan dengan kompetensi kepala sekolah dalam mengelola guru dan staf dalam rangka pendayagunaan sumber daya manusia secara optimal. Jika dikaitkan dengan program literasi membaca, maka program ini juga masih termasuk dalam dimensi kompetensi manajerial terutama

\footnotetext{
${ }^{13}$ Nana Syaodih Sukmadinata, Metode Penelitian Pendidikan (PT Remaja Rosdakarya, 2011), 222.

14 "Peraturan Menteri Pendidikan Nasional RI Nomor 6 tahun 2018 tentang Penugasan Guru sebagai Kepala Sekolah,” diakses $\quad 8 \quad$ April 2020 , https://jdih.kemdikbud.go.id/arsip/Permendikbud_Nomor6_Tahun2018.pdf.

15 "Peraturan Menteri Pendidikan Nasional RI Nomor 13 tahun 2007 tentang Standar Kepala Sekolah/Madrasah,” t.t., https://jdih.kemdikbud.go.id/arsip/Nomor\%2013\%20Tahun\%202007.pdf.

16 "Peraturan Menteri Pendidikan Nasional RI Nomor 6 tahun 2018 tentang Penugasan Guru sebagai Kepala Sekolah."

17 Faizah Faizah dan Ahmad Fauzan, "Strategi Kepala Sekolah Untuk Meningkatkan Motivasi Belajar Siswa Dalam Menghadapi UN Di SMP Negeri 4 Yogyakarta," INSANIA : Jurnal Pemikiran Alternatif Kependidikan 24, no. 1 (3 Juni 2019): 53-72, https://doi.org/10.24090/insania.v24i1.2589.
} 
berkenaan dengan kompetensi kepala sekolah dalam mengelola perubahan dan pengembangan sekolah menuju organisasi pembelajar yang efektif, menciptakan budaya dan iklim sekolah yang inovatif dan kondusif bagi pembelajaran peserta didik, dan mengelola guru dan staf dalam rangka pendayagunaan sumber daya manusia secara optimal. $^{18}$

Adapun membaca adalah kegiatan melihat dan memahami isi tulisan. Membaca juga merupakan proses interaksi antara pembaca dengan dengan teks untuk mendapatkan pesan penulis. ${ }^{19}$ Sedangkan literasi mempunyai makna awal sebagai kemampuan membaca dan menulis yang kemudian berkembang menjadi kemampuan menguasai pengetahuan tertentu. Di Indonesia, literasi pada awalnya diartikan sebagai keberaksaraan yang selanjutnya dimaknai sebagai 'melek' baca dan tulis. Keberaksaraan berkaitan erat dengan program pemberantasan buta huruf, dari sini kemudian berkembang menjadi istilah dan program yang lebih halus dan menyeluruh. Penekanan ini karena kedua kemampuan itu merupakan dasar pengembangan 'melek' berbagai hal. Pada akhirnya pemahaman tentang literasi merambah pada berbagai dimensi yang sering disebut dengan istilah multiliterasi. Perkembangan ini merupakan salah satu alasan literasi membaca terkategorisasi sebagai literasi dasar (basic literacy). ${ }^{20}$

\section{Strategi Implementasi Literasi Membaca di SMA Negeri 1 Kota Kediri}

Sri Yulistiani selaku kepala sekolah SMA Negeri 1 Kota Kediri menyatakan bahwa proses perencanaan literasi membaca merupakan hasil kesepakatan yang diambil melalui rapat dengan melibatkan seluruh komponen yang ada di di SMAN 1 Kota Kediri. Orientasi literasi membaca juga mengarah pada penguatan aspek religius siswa. $^{21}$ Yulistiani juga menjelaskan pelaksanaan literasi membaca berlangsung selama 15 menit sebelum pembelajaran dimulai. Sebagai sebuah program sekolah, orientasi program literasi yang mengarah pada penguatan aspek religiusitas juga telah sesuai dengan visi sekolah, yaitu mencetak manusia unggul spiritual, tinggi intelektual, kreatif,

\footnotetext{
18 "Peraturan Menteri Pendidikan Nasional RI Nomor 13 tahun 2007 tentang Standar Kepala Sekolah/Madrasah.”

${ }^{19}$ Neng Gustini, Dede Rohaniawati, dan Anugrah Imani, Budaya Literasi (Model Pengembangan Budaya Baca Tulis Berbasis Kecerdasan Majemuk Melalui Tutor Sebaya) (Yogyakarta: Deepublish, 2016), 34.

${ }^{20}$ Satgas Gerakan Literasi Sekolah Kemendikbud, Desain Induk Gerakan Literasi Sekolah, 7-11.

${ }^{21}$ Sri Yulistiani, Wawancara, Kediri, Mei 2019.
} 
berwawasan lingkungan dan amanah. ${ }^{22}$ Berikut ini bentuk implementasi strategi yang berlangsung di SMA Negeri 1 Kota Kediri:

1. Struktur

Organisasi adalah kumpulan orang, pembagian kerja, sistem kerja yang sama, sistem hubungan atau sistem sosial. Struktur organisasi adalah hubungan formal antar kelompok dan individu dalam organisasi. Struktur organisasi merupakan pedoman penting bagi para anggota organisasi untuk melaksanakan tugas secara efektif. Sebuah Struktur organisasi menjelaskan dan mengomunikasikan jenis tanggung jawab dan kekuasaan dalam organisasi dan membantu pimpinan dan mengoordinasikan seluruh kegiatannya. Dalam suatu organisasi, pemimpin juga mempunyai pengaruh yang sangat besar dalam menanamkan nilai organisasi sehingga seorang pemimpin harus mampu memberikan contoh konkret pada seluruh anggotanya agar seluruah elemen organisasi dapat menjalankan tugasnya dengan benar dan bertanggung jawab. ${ }^{23}$ Adapun struktur organisasi SMAN 1 Kota Kediri adalah sebagai berikut: Pertama, kepala sekolah. Kedua, komite sekolah. Ketiga, kepala tata usaha/wakil bidang tata usaha. Keempat, wakil kepala sekolah. Wakil kepala sekolah SMAN 1 Kota Kediri terdiri dari wakil kepala sekolah bidang kurikulum, hubungan masyarakat (humas), sarana dan prasarana (sarpras), dan kesiswaan.

\section{Proses}

Pada tahap ini, kepala sekolah mengambil beberapa cara penerapan strategi. Pertama, tahap pembiasaan membaca. Menurut Yulistiani strategi kita adalah taraf pembiasaan yaitu bagaimana seorang siswa mampu membiasakan dirinya dengan membaca apapun, tanpa ada paksaan. Maka taraf pembiasaan ini diintegrasikan kepada seluruh warga sekolah. Di mana 15 menit pertama siswa diminta untuk membaca sebelum pembelajaran dimulai. Kegiatan ini berlaku bagi seluruh kelas dengan dibimbing oleh guru jam pertama guna mengadakan suatu kegiatan literasi membaca. Semua kegatan itu dilakukan setiap hari mulai hari Senin sampai Jumat dengan harapan ketika siswa sudah mulai dibiasakan dengan hal demikian setiap harinya maka mereka mempunyai niat dan kemauan membaca tanpa dipaksa dan disuruh. Oleh karenanya kami membudayakan pembiasaan membaca di sekolah SMAN 1 Kota Kediri. ${ }^{24}$

\footnotetext{
22 "Visi dan Misi | SMA Negeri 1 Kediri," diakses 30 Januari 2019, https://smastkediri.sch.id/read/3/visidan-misi.

${ }^{23}$ Muhammad Arif Syihabuddin, "Budaya Organisasi Lembaga Pendidikan Dalam Perspektif Islam," AtTa'dib: Jurnal Ilmiah Prodi Pendidikan Agama Islam, 19 Desember 2019, 110-19.

24 Yulistiani, Wawancara.
} 
Seperti yang dijelaskan oleh kepala sekolah di atas, Arif Syahputra selaku guru dan penata golongan III bagian kurikulum menambahkan bahwa pada dasarnya kebijakan gerakan literasi sekolah itu berasal dari pusat, artinya dari Kemendikbud, amanat itu sudah kami laksanakan sebelum pembelajaran, karena seluruh komponen literasi itu dasarnya membaca, maka diwajibkan siswa baca buku sebelum pembelajaran. Maka untuk meningkatkan literasi membaca siswa taraf pertama kami melakukan pembiasaan terlebih dahulu". ${ }^{25}$ Penjelasan ini memberikan pemahaman bahwa kepala sekolah telah melakukan program literasi membaca yang dimulai dengan strategi pembiasaan. Karena taraf pembiasaan merupakan salah satu aspek penting dalam mengarahkan kebiasaan positif siswa dan seluruh ekosistem sekolah yang pada akhirnya dapat menjadi bagian dari budaya sekolah.

Kedua, tahap literasi membaca religius. Berkaitan dengan itu, Sri Yulistiani selaku kepala sekolah mengatakan lebih lanjut yaitu, "literasi membaca di SMAN 1 Kota Kediri saat ini diarahkan pada literasi membaca religius yaitu dengan membaca ayat suci Al-Qur'an, belajar tilawah Al-Qur'an dengan baik dan benar serta yang terakhir yaitu membaca terjemahannya. Di mana pelaksanaannya dilakukan oleh guru jam pertama di masing-masing kelas untuk memberikan pengarahan dan pengawasan agar program literasi dapat berlangsung efektif dan efisien. Secara teknis, kegiatan literasi membaca ini dilakukan oleh salah satu siswa maju kedepan yang sudah mendapatkan jadwal sesuai urutan absen, sedangkan yang lain mengikuti siswa yang di depan untuk membaca ayat suci Al-Qur'an". ${ }^{26}$

Di sisi lain, untuk siswa yang nonmuslim bagaimana, baik Katolik, Kristen, Hindu dan Buddha. Sri Yulistiani mengatakan bahwa, bagi siswa nonmuslim, baik itu agama Kristen, Katolik, Hindu dan Buddha dan lain sebagainya, tetap mendapatkan hak yang sama seperti yang dilakukan oleh siswa yang muslim. ${ }^{27}$ Berkaitan dengan hal itu, Arif Syahputra juga menjelaskan, bahwa siswa nonmuslim 15 menit sebelum pembelajaran mereka keluar kelas, menuju ke gazebo tempat yang sudah disediakan oleh sekolah untuk melakukan kegiatan literasi membaca. Di sana mereka akan melaksanakan kegiatan serupa dengan langsung dibimbing oleh bimbingan rohani dari

\footnotetext{
25 Arif Syahputra, Wawancara, Kediri, Mei 2019.

26 Yulistiani, Wawancara.

27 Yulistiani.
} 
masing-masing agama. Setelah selesai melaksanakan kegiatan literasi membaca, siswa nonmuslim kembali ke kelasnya masing-masing". ${ }^{28}$

Dari uraian di atas dapat dikatakan bahwa pelaksanaan literasi membaca yang mengarah kepada literasi membaca religius sejalan dengan kebutuhan pihak sekolah sebagaimana tertuang dalam visi SMAN 1 Kota Kediri. Kegiatan ini juga menunjukkan tren literasi yang berkembang pada sekolah, khususnya di wilayah Kota Kediri sebagaimana temuan Habibah tentang praktik literasi religius di SMA Negeri 2 Kediri yang berlangsung melalui program membaca kitab suci sesuai agama masing-masing dengan dipandu oleh tim literasi membaca religius. ${ }^{29}$ Ini juga menunjukkan ragam praktik literasi yang merupakan perkembangan dari bentuk-bentuk literasi dasar sekaligus upaya-upaya yang dilakukan sekolah menuju sekolah yang literat. Desain induk literasi mencatat 16 keterampilan yang diperlukan peserta didik pada abad 21, antara lain: Pertama, literasi dasar yang mencakup literasi baca tulis, numerasi, sains, digital, finansial, literasi budaya dan kewargaan. Kedua, aspek kompetensi terdiri dari kemampuan berpikir kritis atau pemecahan masalah, kreatifitas, komunikasi, dan kolaborasi. Ketiga, karakter yang terdiri dari keingintahuan, inisiatif, ketekunan, adaptasi, kepemimpinan, dan kepekaan sosial-budaya. ${ }^{30}$

Kegiatan literasi yang diarahkan pada aspek religius siswa juga sejalan dengan kerangka konsep kurikulun 2013 yang salah satu poin pentingnya adalah penguatan pendidikan karakter. Karena orientasi umumnya adalah peningkatan dan keseimbangan antara kompetensi sikap, keterampilan dan pengetahuan. ${ }^{31}$ Dengan begitu, program literasi yang berangkat dari tahap pembiasaan yang kemudian mengarah pada aspek religius juga merupakan usaha menciptakan suasana religius yang pada perkembangan dapat membentuk budaya religius di sekolah. ${ }^{32}$

Ketiga, pembentukan tim literasi. Pembentukan tim literasi adalah salah satu hal yang harus dilakukan karena semenjak diturunkannya kebijakan gerakan literasi sekolah (GLS) pembentukan tim literasi menjadi peran yang sangat penting. Maka dari itu pihak harus membentuk tim literasi. Pada tahap ini, kepala sekolah akan membentuk tim

\footnotetext{
${ }^{28}$ Syahputra, Wawancara.

29 Habibah, "Pengembangan Budaya Literasi Agama Di SMA Negeri 2 Kediri."

${ }^{30}$ Satgas Gerakan Literasi Sekolah Kemendikbud, Desain Induk Gerakan Literasi Sekolah, 7-8.

31 Salma Sunaiyah, "Program Matrikulasi Pada Pembelajaran Kurikulum 2013," Indonesian Journal of Islamic Education Studies (IJIES) 1, no. $1 \quad$ (6 Agustus 2018): 115-33, https://doi.org/10.33367/ijies.v1i1.525.

32 Edi Nurhidin, "Inovasi Pembelajaran Pendidikan Agama Islam (PAI) Melalui Pemanfaatan Media Pembelajaran Kontekstual Dan Pengembangan Budaya Religius Di Sekolah," KUTTAB 1, no. 1 (31 Maret 2017): 1-14, https://doi.org/10.30736/kuttab.v1i1.95.
} 
literasi. Hal ini dikatakan langsung oleh Sri Yuliastiani, tim literasi inilah yang akan menjadi pionir literasi, nanti akan juga dibantu oleh seluruh guru. Karena dengan digalakkannya kegiatan literasi ini, maka otomatis anak punya kemauan membaca. Ketika sudah memliki kemauan membaca secara otomatis siswa akan memiliki wawasan yang luas. Strategi ini kami lakukan karena melihat daya membaca siswa masih rendah. ${ }^{33}$

Tidak hanya sampai di situ langkah berikutnya atau ke depannya untuk pengembangan literasi membaca dan komponen literasi yang lainnya akan kami lakukan dengan terus menerus. Sebagaimana penuturan Sri Yulistiani bahwa, langkah berikutnya untuk pengembangan literasi membaca adalah strategi nilai, dengan mengadakan lomba membaca Al-Qur'an, lomba putra putri literasi dan ada suatu jenis catatan atau jenis buku yang dikemas oleh siswa-siwa dari hasil literasi”. ${ }^{34}$ Setelah strategi di atas sudah tercapai nanti literasi akan dikembangkan dengan mengintegrasikan ke seluruh mata pelajaran. Karena pada abad 21 ini, menyangkut dengan komunikasi, kolaborasi, inovasi. Maka dari itu, setiap anak harus membaca pelajaran yang akan diberikan. Karena literasi bukan hanya membaca saja, ada literasi tulisan, digital dan lain sebagainya.

Penjelasan ini menunjukkan beberapa peran penting kepala sekolah sebagai pemimpin organisasi yang memberikan contoh semangat dalam menjalankan program literasi membaca. Semangat ini dapat dilihat sebagai bentuk perpaduan motivasi internal dan eksternal kepala sekolah dalam mengoptimalkan keberlangsungan suatu program. Bertalian dengan itu, tugas dan fungsi kepala sekolah sebagai motivator memainkan peran sangat penting untuk kemajuan sekolah. Fatikah dan Fildayanati mencatat bahwa kepala sekolah sebagai motivator harus mempunyai strategi tepat untuk memberikan motivasi kepada para guru agar mereka dapat melaksanakan tugas dan fungsinya. ${ }^{35}$ Selain itu, usaha kepala sekolah membentuk tim literasi yang melibatkan seluruh elemen sekolah juga berkesesuaian dengan konsep keanggotaan tim literasi sekolah yang diajukan Antoro yaitu mencakup beragam unsur mulai dari kepala sekolah, guru, pustakawan, komite sekolah dan siswa. ${ }^{36}$ Tanpa keterlibatan dan komitmen seluruh

\footnotetext{
${ }^{33}$ Yulistiani, Wawancara.

${ }^{34}$ Yulistiani.

35 Fatikah dan Fildayanti, "Strategi Kepala Sekolah Dalam Peningkatan Motivasi Dan Etos Kerja Guru Di Sekolah Menengah Atas Negeri Bareng Jombang."

${ }^{36}$ Billy Antoro, Gerakan Literasi Sekolah dari Pucuk hingga Akar: Sebuah Refleksi (Jakarta: Direktorat Jenderal Pendidikan Dasar dan Menengah Kementerian Pendidikan dan Kebudayaan, 2017), 56.
} 
unsur ini, maka apapun program pengembangan sekolah tidak akan berlangsung optimal.

3. Perilaku

Perilaku yang dimaksud pada bagian ini adalah hubungan sosial dalam organisasi yang sangat berkaitan dengan gaya kepemimpinan kepala sekolah dan bagaimana kepala sekolah menggunakan kekuasaannya. Dari data yang penulis temukan, hubungan antara kepala sekolah dengan seluruh ekosistem pendidikan khususnya dengan para guru di SMA Negeri 1 Kota Kediri berjalan dengan baik. Hubungan ini merupakan modal dasar organisasi sekolah untuk terus mengembangkan kualitas sekolah karena hubungan harmonis keseluruhan elemen memudahkan pencapaian tujuan yang ditopang oleh kondisi tim yang solid.

Adapun masalah yang dihadapi, yaitu setiap siswa memiliki karakter yang berbeda dan memiliki kedisiplinan yang berbeda. Begitu juga yang terjadi di SMAN 1 Kota Kediri seperti yang dijelaskan oleh Sri Yulistiani, "terkait hambatan yang kami rasakan saat ini yang pertama masih ada siswa yang terlambat ketika kegiatan literasi membaca dimulai, tapi hal ini bisa diatasi dengan baik. Kedua, masih belum ada perpustakaan mini di setiap sudut-sudut kelas untuk menunjang kegiatan literasi membaca ini". ${ }^{37}$ Dengan kata lain, problem implementasi literasi mempunya dua hambatan yaitu hambatan internal yang berasal dari diri siswa dan hambatan eksternal yang tampak dari keterbatasan fasilitas sekolah.

Kedua, performance. Tahapan ini meliputi kegiatan membandingkan hasil yang diharapkan dengan hasil aktual, mengevaluasi hasil kinerja individual, dan memeriksa progres sesuai dengan tujuan yang telah ditetapkan. Hasilnya dapat dijadikan acuan untuk melihat apakah pelaksanaan strategi mempunyai dampak positif terhadap peningkatan literasi membaca siswa. Apabila literasi membaca ini dilakukan setiap hari, sebagaimana penjelasan di atas dengan melakukan taraf pembiasaan sebelum pembelajaran. Maka kita bisa melihat berapa ayat yang sudah mereka baca, berapa banyak mereka sudah belajar tilawah dengan baik dan benar, serta berapa makna yang mereka pahami yang dijelaskan oleh guru yang membimbingnya.

Apabila dilihat dari segi kuantitas yaitu ketika siswa membaca Al-Qur'an atau kitab suci lainnya sebelum pembelajaran. Misalnya dalam sehari membaca kitab suci selama 15 menit mendapatkan 25 ayat, maka dalam satu bulan mereka sudah mendapat

\footnotetext{
${ }^{37}$ Yulistiani, Wawancara.
} 
wawasan bacaan 750 ayat dan dalam 1 tahun mereka bisa mendapatkan 9.125 wawasan bacaan dari kitab suci dari masing-masing agama. Belum lagi ada kegiatan tambahan literasi membaca di luar dari strategi kepala sekolah. Penjelasan menunjukkan strategi yang dibuat oleh kepala sekolah dalam meningkatkan literasi membaca siswa berdampak baik pada peningkatan literasi membaca siswa sesuai kebutuhan, visi dan misi sekolah SMAN 1 Kota Kediri.

Dari sini, dapat diketahui manfaat minimal dari membaca sebagai bentuk membaca reseptif. ${ }^{38}$ Maka siswa akan terbiasa membaca meskipun tidak memahami makna bacaan yang mereka baca yang dalam pandangan agama merupakan salah satu bentuk ibadah dan kegiatan yang bernilai positif terutama dalam membentuk kebiasaan religius siswa. Apalagi jika program ini kemudian diarahkan pada bentuk membaca yang diarahkan untuk pencarian informasi tertentu sehingga siswa mengetahui makna dari apa yang mereka baca dan perlahan menginternalisasi pemahaman tersebut sebagai suatu pemikiran yang termanifestasikan dalam perilaku sehari-hari.

Program ini juga sangat potensial untuk membantu pertumbuhan kepribadian siswa sebagai insan religius. Karena program ini tampak kompatibel dengan program penguatan karakter dan sekaligus memperkuat pembelajaran pendidikan agama di sekolah. Sejalan dengan itu, kajian Habibah menemukan bahwa pembinaan karakter religius melalui praktik literasi agama (Islam) yang terintegrasi dalam pembelajaran berbasis kelas dan budaya sekolah. $^{39}$ Kenyataan ini menunjukkan pilihan pengembangan bentuk literasi yang berlangsung di SMA Negeri 1 Kota Kediri sebagai pilihan tepat yang berkesesuaian dengan visi dan misi sekolah.

Ketiga, koreksi. Tindakan korektif di sini dapat mengacu pada beberapa hambatan umum yang dialami sekolah dalam menerapkan program literasi terutama berkaitan dengan problem keterlambatan siswa dan perlunya peningkatan fasilitas penunjang seperti penyedian pojok baca berikut dengan keseluruhan perlengkapannya. Mengacu pada keseluruhan proses strategi implementasi literasi membaca di SMAN 1 Kota Kediri. Penulis menemukan beberapa faktor pendukung dan penghambat yang dialami kepala sekolah berdasarkan konsep pengendalian strategi yang dimulai dari

\footnotetext{
38 "Davies membagi kegiatan membaca ke dalam empat bentuk, pertama membaca reseptif yaitu membaca cepat seperti yang kita lakukan ketika membaca narasi. Kedua membaca reflektif, di mana ada jeda berhenti sesaat untuk merenungkan isi bacaan. Ketiga, skimming yaitu membaca cepat yang dimaksudkan untuk memperoleh gambaran umum dari teks. Keempat, scanning yaitu kegiatan membaca yang mengarah pada pencarian informasi tertentu". Lihat, Gustini, Rohaniawati, dan Imani, Budaya Literasi, 17.

39 Maimunatun Habibah dan Siti Wahyuni, "Literasi Agama Islam Sebagai Strategi Pembinaan Karakter Religius Siswa RA KM Al-Hikmah Kediri," Journal of Childhood Education 3, no. 2 (2020): 40-53.
} 
tahap review, performance, dan correction. Secara umum, hal ini merupakan suatu yang wajar dan positif karena faktor-faktor ini dapat dijadikan acuan dalam perbaikan perencanaan implementasi strategi selanjutnya.

Ada tiga faktor pendukung, antara lain: semua komponen sekolah melaksanakan tugas dengan baik dengan saling menghargai, komunikasi, peduli dengan kegiatan literasi. Kedua, pemberian sanksi bagi siswa yang datang terlambat berupa surat pernyataan dan surat panggilan orang tua. Ketiga, akan menyediakan pojok baca untuk memaksimalkan kegiatan literasi. Sedangkan faktor penghambatnya adalah, masih ada siswa yang terlambat dan belum adanya perpustakaan mini di setiap sudut kelas untuk menunjang kegiatan literasi membaca. ${ }^{40}$ Dengan demikian, temuan ini bukan sesuatu yang tiba-tiba atau hanya mendasarkan pada pernyataan kepala sekolah semata. Tapi lebih sebagai hasil yang diperoleh dari tahap pengendalian strategi agar perencanaan dan implementasi program selanjutnya dapat berlangsung lebih efektif dan efisien. Ini juga menunjukkan bahwa kepala sekolah mengetahui problem implementasi literasi membaca yang secara tidak langsung menunjukkan kompetensi sekolah sebagai leader dan manager yang mampu meningkatkan kualitas sekolah dan lulusannya.

\section{Kesimpulan}

Dari penjelasan di atas, dapat diambil kesimpulan bahwa strategi kepala sekolah dalam meningkatkan literasi membaca siswa SMAN 1 Kota Kediri ada tiga, antara lain: strategi yang pertama dilakukan kepala sekolah adalah taraf pembiasaan membaca yaitu bagaimana siswa mampu membiasakan dirinya dengan membaca apapun, tanpa ada paksaan. Strategi yang kedua strategi adalah literasi membaca diarahkan kepada literasi membaca religius dengan membaca ayat suci Al-Qur'an, belajar tilawah Al-Qur'an dengan baik dan benar serta yang terakhir yaitu membaca terjemahannya. Bagi siswa nonmuslim tetap melaksanakan kegiatan serupa di tempat berbeda dengan bimbingan khusus dari bimroh. Strategi yang ketiga, kepala sekolah membentuk tim literasi, tim literasi inilah yang akan menjadi pionir literasi, nanti akan juga dibantu oleh seluruh guru. Dari sini juga didapatkan beberapa faktor pendukung yaitu kesediaan semua komponen sekolah untuk melaksanakan kegiatan literasi, pemberian sanksi bagi siswa yang terlambat, dan akan menyediakan pojok baca. Bertalian dengan faktor pendukung

\footnotetext{
${ }^{40}$ Yulistiani, Wawancara.
} 
tersebut, faktor penghambatnya adalah keterlambatan siswa dan belum adanya perpustakaan mini di setiap sudut kelas.

\section{Daftar Rujukan}

Antoro, Billy. Gerakan Literasi Sekolah dari Pucuk hingga Akar: Sebuah Refleksi. Jakarta: Direktorat Jenderal Pendidikan Dasar dan Menengah Kementerian Pendidikan dan Kebudayaan, 2017.

Faizah, Faizah, dan Ahmad Fauzan. "Strategi Kepala Sekolah Untuk Meningkatkan Motivasi Belajar Siswa Dalam Menghadapi UN Di SMP Negeri 4 Yogyakarta." INSANIA : Jurnal Pemikiran Alternatif Kependidikan 24, no. 1 (3 Juni 2019): 53-72. https://doi.org/10.24090/insania.v24i1.2589.

Fatikah, Noor, dan Fildayanti. "Strategi Kepala Sekolah Dalam Peningkatan Motivasi Dan Etos Kerja Guru Di Sekolah Menengah Atas Negeri Bareng Jombang." Indonesian Journal of Islamic Education Studies (IJIES) 2, no. 2 (30 Desember 2019): 167-82. https://doi.org/10.33367/ijies.v2i2.989.

Gustini, Neng, Dede Rohaniawati, dan Anugrah Imani. Budaya Literasi (Model Pengembangan Budaya Baca Tulis Berbasis Kecerdasan Majemuk Melalui Tutor Sebaya). Yogyakarta: Deepublish, 2016.

Habibah, Maimunatun. "Pengembangan Budaya Literasi Agama Di SMA Negeri 2 Kediri." Indonesian Journal of Islamic Education Studies (IJIES) 2, no. 2 (2019): 203-15. https://doi.org/10.33367/ijies.v2i2.1110.

Habibah, Maimunatun, dan Siti Wahyuni. "Literasi Agama Islam Sebagai Strategi Pembinaan Karakter Religius Siswa RA KM Al-Hikmah Kediri." Journal of Childhood Education 3, no. 2 (2020): 40-53.

Lathif, Ilman. "Rendahnya Minat Baca Pelajar Kota Kediri - Kompasiana.com." Diakses $\quad 30 \quad$ Januari 2019. https://www.kompasiana.com/muhammadilmanlathif/552b7d8c6ea834c06a8b45 86/rendahnya-minat-baca-pelajar-kota-ked iri.

Makhromi, Makhromi, dan Mahbub Budiono. 'Kontribusi Kepala Sekolah Sebagai Manajer Untuk Meningkatkan Mutu Pendidikan Di MTs Negeri Kanigoro Kras Kediri." Indonesian Journal of Islamic Education Studies (IJIES) 2, no. 1 (31 Juli 2019): 78-93. https://doi.org/10.33367/ijies.v2i1.833.

Margono, S. Metodologi Penelitian Pendidikan. Jakarta: Rineka Cipta, 2003.

Media, Kompas Cyber. "Per Hari, Rata-rata Orang Indonesia Hanya Baca Buku Kurang dari Sejam.” KOMPAS.com. Diakses 30 Januari 2019. https://nasional.kompas.com/read/2018/03/26/14432641/per-hari-rata-rataorang-indonesia-hanya-baca-buku-kurang-dari-sejam.

Nurhidin, Edi. 'Inovasi Pembelajaran Pendidikan Agama Islam (PAI) Melalui Pemanfaatan Media Pembelajaran Kontekstual Dan Pengembangan Budaya Religius Di Sekolah.” KUTTAB 1, no. 1 (31 Maret 2017): 1-14. https://doi.org/10.30736/kuttab.v1i1.95. 
"Peraturan Menteri Pendidikan Nasional RI Nomor 6 tahun 2018 tentang Penugasan Guru sebagai Kepala Sekolah.” Diakses 8 April 2020. https://jdih.kemdikbud.go.id/arsip/Permendikbud_Nomor6_Tahun2018.pdf.

"Peraturan Menteri Pendidikan Nasional RI Nomor 13 tahun 2007 tentang Standar Kepala Sekolah/Madrasah," t.t. https:/jdih.kemdikbud.go.id/arsip/Nomor\%2013\%20Tahun\%202007.pdf.

Satgas Gerakan Literasi Sekolah Kemendikbud. Desain Induk Gerakan Literasi Sekolah. Jakarta: Direktorat Jenderal Pendidikan Dasar dan Menengah Kementerian Pendidikan dan Kebudayaan, 2016.

Sukmadinata, Nana Syaodih. Metode Penelitian Pendidikan. PT Remaja Rosdakarya, 2011.

Sunaiyah, Salma. "Program Matrikulasi Pada Pembelajaran Kurikulum 2013." Indonesian Journal of Islamic Education Studies (IJIES) 1, no. 1 (6 Agustus 2018): 115-33. https://doi.org/10.33367/ijies.v1i1.525.

Suragangga, I. Made Ngurah. "Mendidik Lewat Literasi untuk Pendidikan Berkualitas." Jurnal Penjaminan Mutu 3, no. 2 (31 Agustus 2017): 154-63. https://doi.org/10.25078/jpm.v3i2.195.

Syahputra, Arif. Wawancara, Kediri, Mei 2019.

Syihabuddin, Muhammad Arif. "Budaya Organisasi Lembaga Pendidikan Dalam Perspektif Islam." At-Ta'dib: Jurnal Ilmiah Prodi Pendidikan Agama Islam, 19 Desember 2019, 110-19.

"Visi dan Misi | SMA Negeri 1 Kediri." Diakses 30 Januari 2019. https://s mastkediri. sch.id/read/3/visi-dan-misi.

Wandasari, Yulisa. "Implementasi Gerakan Literasi Sekolah (GLS) Sebagai Pembentuk Pendidikan Berkarakter." JMKSP (Jurnal Manajemen, Kepemimpinan, Dan Supervisi Pendidikan) 2, no. 2 (28 Desember 2017). https://doi.org/10.33369/jmksp.v2i2.1480.

Widayoko, Agus, Supriyono Koes H, dan Muhardjito Muhardjito. "Analisis Program Implementasi Gerakan Literasi Sekolah (GLS) Dengan Pendekatan Goal-Based Evaluation." Jurnal Tatsqif 16, no. 1 (9 Juli 2018): 78-92. https://doi.org/10.20414/jtq.v16i1.134.

Yulistiani, Sri. Wawancara, Kediri, Mei 2019.

Yulmawati, Yulmawati. "Strategi Kepemimpinan Kepala Sekolah Dalam Meningkatkan Mutu Pendidikan SD Negeri 03 Sungayang." JMKSP (Jurnal Manajemen, Kepemimpinan, Dan Supervisi Pendidikan) 1, no. 2 (1 April 2017). https://doi.org/10.33369/jmksp.v1i2.1012. 